\title{
Evidence on the costs of changes in financial reporting frameworks in the public sector
}

\author{
Nives Botica Redmayne, Fawzi Laswad and Dimu Ehalaiye* \\ School of Accountancy, Massey University, New Zealand
}

\begin{abstract}
This paper examines the impact of changes in reporting frameworks on New Zealand (NZ) public sector audit costs in terms of both audit fees and effort. Audit costs increased with the adoption of both International Financial Reporting Standards (IFRS) and International Public Sector Accounting Standards (IPSAS) reporting frameworks. The costs of auditing across various financial reporting frameworks in the public sector is shown to be significantly influenced by auditors' specialization.
\end{abstract}

\section{IMPACT}

Many countries are changing their public sector reporting from a cash basis to IPSAS and these changes can have significant cost implications in terms of audit fees and audit effort. This paper will be of interest to accounting standard-setters, regulators and policy-makers in countries that are transitioning to IPSAS reporting or considering IPSAS. The authors suggest planning for an increase in audit fees when assessing the costs and benefits of adopting new reporting frameworks.

Keywords: Audit fees; audit hours; IPSAS; New Zealand; public sector

*Corresponding author

Dimu Ehalaiye

School of Accountancy, Massey University,

Private Bag 11222,

Palmerston North, New Zealand

o.ehalaiye@massey.ac.nz

Accepted manuscript. Please cite this article as:

Botica Redmayne, N., Laswad, F., \& Ehalaiye, D. (2021). Evidence on the costs of changes in financial reporting frameworks in the public sector. Public Money \& Management, 41(5), 368-375. 


\section{Introduction}

All around the world, financial reporting in the public sector is changing. Significant transitions have been made by several countries from the traditional cash basis of accounting in the public sector to accrual accounting and, subsequently, to an international financial reporting standards (IFRS) based financial reporting framework. Recently, there has been a move towards the use of international public sector accounting standards (IPSAS) in a number of countries. Despite the growing application of IPSAS, and the changes in reporting regimes from the traditional cash accounting for financial reporting in the public sector, little is known about the consequences of these changes - especially regarding their benefits and costs. Previous studies on changes in financial reporting frameworks in the public sector have focused on the motivations for such changes and the expected effects of such changes (for example Guthrie, 1998; Carlin, 2005; Carvalho et al., 2007; Robb and Newberry, 2007; Wynne, 2008; Christiaens et al., 2010; Roje et al., 2010; Brusca et al., 2013; Christiaens et al., 2015). However, these studies do not evaluate ex post empirical evidence of the consequences of these changes. Notable exceptions are two New Zealand (NZ) studies, Botica Redmayne and Laswad (2013) and Trewavas et al. (2012) that document, respectively, the cost of reporting regime changes and the impact of such changes in the mid 2000s on NZ public sector entities' financial statements. Also, Pilcher and Dean (2009a; 2009b) and Ahmed and Alam (2012) provide some evidence on the costs of changing to the IFRS based financial reporting framework in the Australian public sector.

The External Reporting Board (XRB) (NZ's current accounting standard-setter) identified four key areas of potential costs that result from a change in the financial reporting framework (XRB, 2012):

- The costs to users in learning the new basis on which financial statements have been prepared.

-The costs to preparers in implementing those new standards.

-The costs to auditors in auditing against the new financial reporting regime.

-The costs to standard-setters in developing the new standards.

An understanding of these costs has significant implications when considering the costbenefit analysis in the evaluation of current financial reporting frameworks and the implementation of new reporting frameworks in public sectors around the world.

This paper provides evidence of the costs of changing financial reporting frameworks in the public sector. In particular, the paper focuses on the auditing costs related to changes in financial reporting frameworks in the NZ public sector. NZ has undergone significant changes in the financial reporting framework of its public sector. Notable changes include a change from NZ Generally Accepted Accounting Principles (GAAP) based on accrual accounting to IFRS based standards for financial reporting in the NZ public sector in 20052007 and, in 2015, the change to NZ public benefit entities (PBE) standards based on IPSAS. 
Thus, our study investigated the cost of financial reporting framework changes and compared the costs of the transitions from NZ GAAP to NZ IFRS and from NZ IFRS to NZ PBE/IPSAS.

We found that the costs of audit - measured in effort (hours) and fees-increased overall with the introduction of both NZ IFRS and IPSAS financial reporting frameworks, with the increases in audit effort and fees being more pronounced during the transition to the IFRS based reporting framework than to IPSAS. In particular, we found that, for the central government in NZ, audit effort did not significantly increase with the introduction of the IPSAS reporting regime. This confirms the case that the change from NZ GAAP to NZ IFRS was more complex than the change from NZ IFRS to IPSAS. We also found that the costs of auditing across various financial reporting frameworks was significantly influenced by the level of specialization of the auditors involved.

\section{Financial reporting frameworks in the public sector-from cash accounting to IPSAS}

Traditionally, the cash basis of accounting was used for public sector financial reporting around the world (OECD, 2002; Carlin, 2005). Under cash accounting, cash receipts, payments and balances are recorded at the time cash is exchanged, hence financial statements using cash accounting show the sources of cash receipts, the allocation of cash expenditure, and provide a comparison of actual against budgeted expenditures (Guthrie, 1998). In the English-speaking world, several developed countries, such as Australia, the UK, the USA, Canada and NZ (Carlin, 2005; Wynne, 2008), transitioned to the use of accrual accounting (GAAP) for financial reporting following a number of public sector management reforms between the 1970s and the 1990s. The philosophies underlying these changes were New Public Management (NPM) and New Public Financial Management (NPFM) (Lapsley et al., 2009; Trewavas et al., 2012).

Accrual accounting was expected to increase efficiency in the public sector, as well as improving accounting for assets, cost management, accountability and financial comparability (Guthrie, 1998; Robb and Newberry, 2007). However, there has been significant debate about whether these expected benefits actually happen and whether the benefits of accrual accounting outweigh the costs of implementing it in the public sector (Ellwood, 2003; Ellwood and Newberry, 2007).

The primary argument against accrual accounting in the public sector is that it is not fit for purpose because most of the benefits of accrual accounting are not relevant to the public sector. This is because, unlike private sector entities, the purpose of public sector entities is not to make a profit, and as such an accounting system based on accrual accounting and developed for the private sector will not work effectively in the public sector (Guthrie, 1998; Hodges and Mellet, 2003; Carlin, 2005; Wynne, 2008; Trewavas et al., 2012). 
Another change in financial reporting frameworks for the public sector resulted from the adoption of IFRS. Some of the developed countries that had moved their financial reporting framework in the public sector from cash accounting to accrual accounting also adopted IFRS for their public sector. Notably, Australia adopted IFRS in 2004 for local government entities, with full compliance taking place from the 2005/2006 financial year (Pilcher and Dean, 2009a; 2009b). NZ adopted IFRS for the public sector with compliance from 1 January 2007, with the option of early compliance from 1 January 2005. New Zealand's adoption of IFRS in the public sector was comprehensive as it covered all government accounts. This was a legacy of the NZ policy of implementing a sector-neutral approach to financial reporting in both public and private sectors, where the difference in accounting treatment is driven by differences in the nature of transactions and not by ownership or the objectives of the reporting entity (Bradbury and van Zijl, 2007; Bradbury and Baskerville, 2008). Apart from NZ and Australia, other countries did not adopt IFRS wholesale for their government accounts; rather, they continued to use accrual accounting or cash accounting or moved towards an IPSAS based financial reporting framework. The introduction of reporting requirements under IFRS in the NZ and Australian public sectors has been found to be costly and time consuming, and it has tended to dominate management accounting systems (Pilcher and Dean, 2009a, 2009b; Botica Redmayne and Laswad, 2013). Ahmed and Alam (2012) found no major significant changes in the overall financial position (except for liabilities) of Australian local government entities post adoption of IFRS for financial reporting in Australia.

The most recent change in financial reporting frameworks in the public sector is the move towards using IPSAS (Aggestam-Pontoppidan, 2011). IPSAS has been described by some scholars as inspired by IFRS, with some modifications to suit particular areas of public sector accounting (Christiaens et al., 2010; Lande and Rocher, 2011; Oulasvirta, 2014; Grossi and Steccolini, 2015). Studies of the effects of adoption of IPSAS in the public sector are gaining in importance because until quite recently little has been known about the process of adoption of IPSAS. Benito et al. (2007) and Brusca and Condor (2002) conducted comparative accounting studies in the public sector. They found that many governments are reforming their accounting systems to accrual accounting and that there is a trend to harmonization in the public sector which includes the adoption of IPSAS. They also found that the development of national accounting systems is a function of different institutional attributes and environments.

Carvalho et al. (2007) and Christiaens et al. (2010) found great diversity in the way and the timing of IPSAS adoption process in their international studies. This was confirmed by Brusca et al. (2013) on a national level and Grossi and Soverchia (2011) in the European context, who found that an important stimulus to the harmonization of reporting and the adoption of IPSAS is support from international organizations such as the OECD, United Nations and European Commission. Christiaens et al.'s (2010) comparative European study was followed by Christiaens et al.'s (2015) study where they investigated IPSAS adoption in 59 countries. They found that countries that adopt IPSAS are looking for improvements in the international comparability of their financial information, and so facilitate the 
consolidation process of the whole country's financial statements. However, they point to the necessity of enforceability of IPSAS to overcome a slow international adoption process.

IPSAS has also gained favour in developing countries, especially in countries that rely on international lenders and donors (Adhikari and Mellemvik, 2015). Roje et al. (2010) reported some southern European countries see IPSAS standards as a way to better understand public expenditure; they also pointed out that the costs and benefits of the implementation of accrual accounting and IPSAS are not well understood.

\section{Costs of changes in financial reporting frameworks in the public sector}

Although there is a significant discussion in the academic literature about the motivations and benefits of changes in financial frameworks in the public sector, real evidence of the costs of such changes is very limited (Wynne, 2008; Trewavas et al., 2012; Botica Redmayne and Laswad, 2013; Laswad and Botica Redmayne, 2015). The few studies that have investigated the costs of transitioning from cash to accrual accounting in the public sector have argued that the costs of implementing accrual accounting were substantial, because it is more complex than cash accounting (Hepworth, 2003). Further, accrual accounting requires the employment of significantly more professionally qualified accountants, of which governments have traditionally had only a few, in contrast to the private sector (Hyndman and Connolly, 2005). Wynne (2007) noted that the number of professionally qualified accountants working in the UK central government increased nearly fourfold from about 600 in 1989 to 2200 in 2003, coinciding with the period over which accrual based accounting was introduced in the UK. Furthermore, the audit fees for the UK National Audit Office (NAO) rose by $67 \%$ with the introduction of accrual accounting in 2001/2002 (NAO, 2002), suggesting that the change in accounting frameworks in the UK public sector has been very costly.

With regard to the change from accrual accounting to the IFRS based financial reporting framework, Botica Redmayne and Laswad (2013) provided insight into the costs of change of the reporting regime in the NZ public sector by investigating the implementation of IFRS in that setting. They compared the pre-adoption year with the first year of adoption of the IFRS reporting framework for the 2005-2007 period for all segments and public sector entities. Their results indicated a substantial increase in audit fees and audit effort in the first year of change.

The change towards IPSAS based financial reporting is gaining momentum around the world, and some key arguments for IPSAS include the enhancement of transparency in government financial reporting (Ball, 2012) and promotion of harmonization and comparability in public sector accounting (Rossi et al., 2016; Brusca and Martinez, 2015). However, there is no real empirical evidence on the costs of implementing the IPSAS financial reporting framework. This paper provides some evidence on the costs of transitioning to an IFRS based reporting framework and, subsequently, to an IPSAS based 
reporting framework and therefore contributes to debates about the costs and benefits of changes in the financial reporting frameworks in the public sector.

\section{Financial reporting framework changes in the NZ public sector}

Accrual accounting became mandatory for public sector entities in NZ after 1 July 1991 (see Figure 1) following the enactment of the Public Finance Act 1989. In addition, generally accepted accounting principles (GAAP) as used in private sector financial reporting were adopted at the same time. The changes were criticised by some scholars because they argued that public sector financial reporting has different objectives, processes, stakeholders and obligations when compared with the private sector (Pallot, 1991, 1992, 1998; Newberry, 2002; Newberry and Pallot, 2005, 2006; Robb and Newberry, 2007). Reporting under IFRS for all reporting entities in NZ was encouraged in 2005 for early adopters. However, all public sector entities had to comply with NZ IFRS in their financial reporting for periods commencing from 1 January 2007. This was a consequence of the then sector-neutral approach to financial reporting.

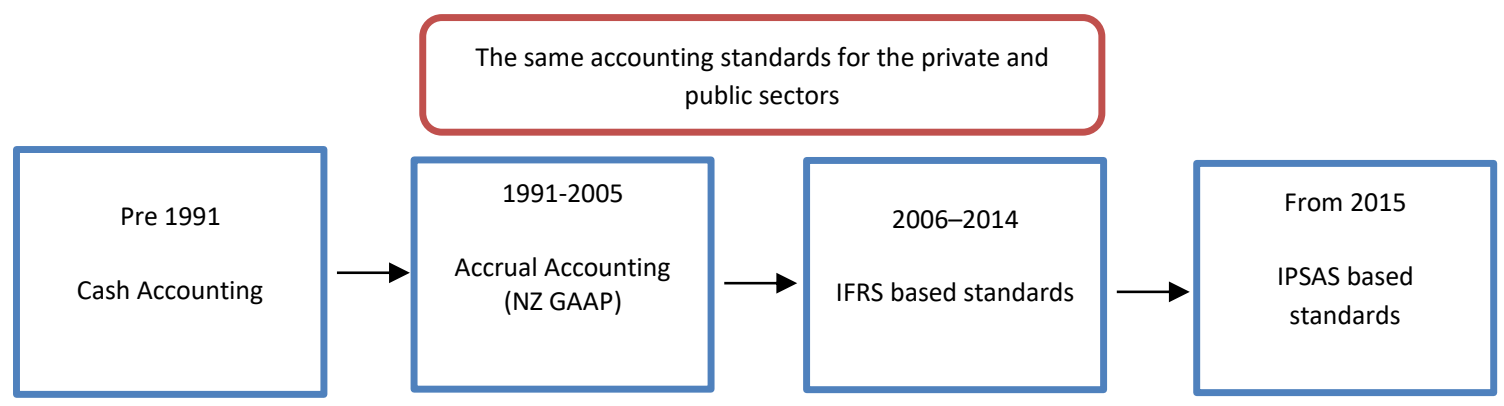

Figure 1. The reporting frameworks in the NZ public sector

The relevance of complying with IFRS in public sector reporting was questioned both internationally and nationally (GASB, 2006; Robb and Newberry, 2007; Brady, 2007; Stevenson, 2010). Criticism of IFRS as applied to NZ public sector reporting was centred around the requirements for voluminous disclosures with questionable relevance. In response to problems and inconsistencies in financial reporting, and assurance of financial statements in the public and the not-for-profit sectors in NZ, in September 2009 the NZ Ministry of Economic Development and the NZ Accounting Standards Reporting Board decided to revise the statutory framework for financial reporting. Part of the revision process was a proposal that the NZ not-for-profit sector, which includes public sector entities, should abandon sector neutral financial reporting and comply with NZ Public Benefit Entities Accounting Standards (NZ PBE Accounting Standards), which are based on the IPSAS.

In September 2011, NZ adopted a change to reporting in the public sector and moved to a multi-standard approach, where public benefit entities' reporting frameworks were based on IPSAS (XRB, 2012). Consequently from 2015, NZ public benefit entities, including public 
sector entities, apply sector-specific reporting. The transition to NZ PBE standards was expected to be a lot less onerous than the transition to IFRS from NZ GAAP in 2005, because NZ IFRS and NZ PBE standards are based on IPSAS and were largely aligned at that stage. However, the NZ PBE standards introduced 39 new standards and a new framework (PwC, 2016); therefore, some differences between the reporting regimes were expected (EY, 2016). In addition, the changes in the reporting regimes were also expected to result in some significant changes in terms of accounting and disclosures (EY, 2016). The External Reporting Board (XRB) acknowledged that some costs could be involved in changing the framework for financial reporting in the NZ public sector. However, it expected these costs to be small compared to the costs of adopting NZ IFRS. This is illustrated by XRB's statement in its proposed accounting standards framework as follows (XRB, 2012, pp. 2728):

Any change involves a cost - to users in learning the new basis on which financial statements have been prepared; to preparers in implementing those new standards; to auditors in auditing against those standards; and to standard-setters in developing the new standards. The XRB has done an extensive analysis of the extent of change required to move from $N Z$ IFRS to PAS (NZ PBE standards)... at this point in time there is a high degree of alignment between the two suites of standards. The cost of adopting PAS is therefore relatively small and is anticipated to be very small compared to the cost of adopting NZ IFRS in 2005 to 2007. The XRB considers that this cost is heavily outweighed by the potential improvement in meeting user-needs. Further, the degree of current alignment and the likely future divergence means that the cost of the change is likely to be lower now than in the future.

Thus, given the differences that the changes in financial reporting regimes brought in NZ public sector accounting, which were expected to result in some attendant costs, we decided to investigate the consequences of the changes in financial reporting frameworks in the NZ public sector with a focus on the cost and effort expensed on auditing public sector entities. Our study follows Botica Redmayne and Laswad's (2013) study, which investigated consequences of the change from NZ GAAP (accrual accounting) reporting framework to IFRS reporting in the NZ public sector using the same methodology. This study reported here provides more comprehensive evidence on the costs of transitioning from the accrual financial reporting framework to the IFRS based reporting framework and, subsequently, to the IPSAS based reporting framework in the NZ public sector based on the cost and effort of auditing.

\section{Data collection and analysis plan}

Data on the audit fees and the audit hours in the audits of NZ public sector entities for the fiscal years 2001-2017 was obtained from the NZ Office of the Auditor-General (OAG). While audit fees data is public information and disclosed in the annual reports of the reporting entities, the data about actual audit hours is proprietary data. The 17-year sample 
consisted of 6,113 entity-year observations.

During the period 2001-2017, NZ public sector entities used three reporting frameworks, namely: the NZ sector neutral reporting framework (NZ GAAP) based on accrual accounting for the period 2001-2005; a sector neutral IFRS standards (IFRS) for the period 2006-2014; and, from 2015-2017, sector-specific IPSAS. The adoption of IPSAS in 2015 was limited to public benefit entities and therefore excluded commercial entities in the public sector. 'Public benefit entities' are entities whose primary objective is to provide goods and services to the general public, or for the public good, rather than to make a profit.

To evaluate the costs of the changes in these financial reporting frameworks in NZ, we compared the audit fees and audit effort (audit hours) (proxies for costs of the changes in reporting frameworks) under the three reporting frameworks and tested for significant differences among the three periods. Consistent with Trewavas et al. (2012), we classified public sector entities into six subsectors according to their similarities in purpose, function, funding and structure. The subsectors were central government, health boards, crown entities, commercial entities, higher education and local government.

We also compared hourly audit fees across audit providers and reporting frameworks, to discover whether there were any significant differences in costs based on the particular audit provider and across the different reporting frameworks.

\section{Results and discussion}

Table 1 (Panel A) identifies the types of audit firms in the study sample. Audit New Zealand, a public sector auditing unit of the OAG, is the dominant provider of audit services in the public sector and performed $70 \%$ of the audits during the study period, followed by the 'Big 4 ' firms with $28 \%$ of the audits. Non-Big 4 firms audited a small number of public sector entities in the study sample - only $2 \%$ of the audits. In the NZ public sector, commerciallyoriented entities' audits, the Big 4 firms have a strong presence with $62 \%$ of the audits. The commercially-oriented public sector entities, except for residual ownership, are profit oriented business entities similar to private sector corporate firms. All corporate entities in NZ, in both the public and private sectors, operate under the same legislative requirements: the Companies Act 1993 and the Financial Reporting Act 2013. The commercial entities in the public sector use IFRS rather than IPSAS.

\section{Financial reporting frameworks changes, audit fees and effort}

Table 1 (Panel B) compares the mean audit fees and audit effort across the three frameworks: NZ GAAP, IFRS and IPSAS. The results indicate that the audit fees and effort increased with the introduction of each new reporting framework. Most significantly, the introduction of the IFRS reporting framework in the NZ public sector required fair value reporting, 
including more extensive reporting on financial instruments, which resulted in increased audit effort and audit cost (Trewavas et al., 2012). The only exception was central government where audit effort did not increased with the introduction of IPSAS. This is largely due to the effects of the introduction of IPSAS 23 that had a more significant effect on local authorities and tertiary educational entities than it did on central government. IPSAS 23 requires accounting and classification of revenue in exchange and non-exchange transactions. Local authorities and tertiary educational entities are required to separately account for their activities that are funded through central government appropriations versus those transactions that are funded through levies, fees and taxation.

Table 1. Audit providers and audit fees and effort across reporting frameworks.

Panel A: Public sector audits and audit service providers 2001-2017

\begin{tabular}{lccccccc}
\hline & \multicolumn{1}{c}{ Audit NZ/OAG } & Big 4 firms & \multicolumn{3}{c}{ Other firms } & & \\
\hline & No & $\%$ & No & $\%$ & No & $\%$ & \\
Central government & 735 & $77 \%$ & 208 & $22 \%$ & 9 & $1 \%$ & 952 \\
Health & 278 & $74 \%$ & 97 & $26 \%$ & 0 & $0 \%$ & 375 \\
Crown & 833 & $68 \%$ & 350 & $28 \%$ & 51 & $4 \%$ & 1,234 \\
Commercial & 376 & $37 \%$ & 624 & $62 \%$ & 10 & $1 \%$ & 1,010 \\
Higher education & 477 & $83 \%$ & 78 & $14 \%$ & 18 & $3 \%$ & 573 \\
Local government & $\underline{1,573}$ & $\underline{80 \%}$ & $\underline{356}$ & $\underline{18 \%}$ & $\underline{40}$ & $\underline{2 \%}$ & $\underline{1,969}$ \\
& 4272 & $70 \%$ & 1713 & $28 \%$ & 128 & $2 \%$ & 6,113 \\
\hline
\end{tabular}

Panel B: Comparing audit fees and efforts across the three reporting frameworks

\begin{tabular}{|c|c|c|c|c|c|c|c|c|c|c|c|c|c|c|}
\hline & \multicolumn{6}{|c|}{ Audit fees (\$NZ) } & \multicolumn{8}{|c|}{ Audit hours } \\
\hline & \multicolumn{2}{|c|}{ NZ GAAP } & \multicolumn{2}{|c|}{ IFRS } & \multicolumn{2}{|c|}{ IPSAS } & & \multicolumn{2}{|c|}{ NZ GAAP } & \multicolumn{2}{|c|}{ IFRS } & \multicolumn{3}{|c|}{ IPSAS } \\
\hline & $N$ & Mean & $N$ & Mean & $N$ & Mean & & $N$ & Mean & $N$ & Mean & $N$ & Mean & \\
\hline All entities & 1,599 & $68,556.60$ & 3,431 & $105,241.99$ & 940 & $111,388.75$ & $* * *$ & 1,599 & 664.9 & 3,431 & 822.71 & 940 & 847.55 & $* * *$ \\
\hline $\begin{array}{l}\text { Central } \\
\text { government }\end{array}$ & 263 & $124,159.56$ & 500 & $155,006.10$ & 186 & $151,733.54$ & $*$ & 263 & $1,134.09$ & 500 & $1,105.59$ & 186 & $1,040.18$ & \\
\hline Health & 107 & $64,714.87$ & 194 & $112,349.72$ & 71 & 136.990 .38 & $* * *$ & 107 & 673.61 & 194 & 908.52 & 71 & $1,085.28$ & $* * *$ \\
\hline Crown & 306 & $49,665.91$ & 655 & $76,874.26$ & 215 & $91,002.80$ & $* * *$ & 306 & 509.84 & 655 & 618.34 & 215 & 700.82 & $* * *$ \\
\hline Commercial & 241 & $65,463.34$ & 710 & $117,973.67$ & & & $* * *$ & 241 & 580.51 & 710 & 949.94 & & & $* * *$ \\
\hline $\begin{array}{l}\text { Higher } \\
\text { education }\end{array}$ & 177 & $46,140.03$ & 285 & $94,887.14$ & 98 & $81,710.18$ & $* * *$ & 177 & 519.1 & 285 & 814.21 & 98 & 691.66 & $* * *$ \\
\hline $\begin{array}{l}\text { Local } \\
\text { government }\end{array}$ & 505 & $61,389.42$ & 1,086 & $87,790.27$ & 370 & $105,901.36$ & $* * *$ & 505 & 604.04 & 1,087 & 719.54 & 370 & 831.65 & $* *$ \\
\hline
\end{tabular}

Table 2 Panel A provides a comparison of actual with quoted audit fees and hours across the reporting frameworks. This panel shows that actual fees are lower than quoted and this is both significant during NZ GAAP and the overall period. Actual audit hours are higher than quoted for all reporting frameworks. These differences are significant at 0.001. Initial 
anecdotal evidence in discussions with practising auditors in $\mathrm{NZ}$ public sector was that auditors did expect to increase both the audit effort and audit fees following each change in the reporting framework, however, that was more pronounced with the change from NZ GAAP to IFRS than from IFRS to IPSAS based standards. That is because the first change was more complex. In that way, this study provides evidence of the increasing but gradual costs of change in financial reporting frameworks. Additionally, our initial anecdotal evidence indicated that public sector auditors had to absorb some of the cost of changing from IFRS to IPSAS due to policy reasons and the pressures surrounding the second change. Further research of the costing and decision-making around the audit costs related to the transitions could collect more evidence through surveys and indepth interviews of auditors in the public sector.

\section{Financial reporting framework changes, audit providers and audit fees}

Table 2 Panel B shows the mean hourly audit fees across audit providers and frameworks. Average audit fees is the total actual audit fees divided by actual audit hours. The results show statistically significant differences at 0.001 in the average audit fees charged by each of the groups of audit providers in the NZ public sector across the three financial reporting frameworks. Overall, under each of the reporting frameworks, the Big 4 audit firms had the highest average hourly audit fees. Audit NZ had the second highest mean audit fees overall, as well as during the transition from NZ GAAP and to IFRS. While the other firms had the lowest hourly audit fees overall of the three groups of audit providers, during the change to the IPSAS framework they had higher audit fees in comparison to Audit NZ .

These findings are not surprising as Audit NZ is the market leader when it comes to specialization in the NZ public sector. Audit NZ is followed by the Big 4 auditors who are generally specialized in specific public sector sub-sectors (for example, $\mathrm{PwC}$ specializes in the health sector and the energy sector). That means that smaller non-specialist firms, unlike Audit NZ and the Big 4, generally have higher hourly audit fees arising from not having the ability to capture 'spill on' effects from specializations in the public sector. This is consistent with Solomon et al. (1999), Owhoso et al. (2002) and Mayhew and Wilkins (2003), all of whom suggest that industry specialization by auditors, leads to a decrease in the costs of performing audits in that particular industry. 
Table 2. Comparing audit fees, hours, and hourly audit fees.

Panel A: Actual and quoted audit fees and hours across reporting frameworks

Mean audit fees $(\$ N Z)$
Mean audit hours

\begin{tabular}{|c|c|c|c|c|c|c|c|c|}
\hline & Actual & Quoted & Difference & & Actual & Quoted & Difference & \\
\hline & $68,556.60$ & $69,044.65$ & $(488.06)$ & & 664.90 & 629.513 & 35.77 & $* * *$ \\
\hline \multicolumn{9}{|l|}{ NZ GAAP } \\
\hline & $105,251.99$ & $105,505.07$ & (253.40) & & 8022.71 & 707.32 & 115.38 & $* * *$ \\
\hline \multicolumn{9}{|l|}{ IFRS } \\
\hline & $111,388.75$ & $124,324.08$ & $(12,935.33)$ & & 847.35 & 746.41 & 101.13 & $* * *$ \\
\hline IPSAS & & & & & & & & \\
\hline $\begin{array}{l}\text { All reporting } \\
\text { frameworks }\end{array}$ & $96,389.78$ & $98,702.85$ & $(2,313.07)$ & $* * *$ & 784.35 & 692.01 & 91.81 & $* * *$ \\
\hline
\end{tabular}

Panel B: Comparing mean hourly audit fees (NZD) across audit providers and reporting frameworks

\begin{tabular}{lcccc}
\hline & Audit NZ/OAG & Big 4 & Other firms & \\
\hline NZ GAAP & 95.71 & 107.33 & 73.27 & $* * *$ \\
IFRS & 115.70 & 135.91 & 113.91 & $* * *$ \\
IPSAS & 118.82 & 148.34 & 143.61 & $* * *$ \\
All reporting frameworks & 110.57 & 130.20 & 109.51 & $* * *$ \\
\hline
\end{tabular}

***Significant at $0.01 \%, * *$ significant at $1 \%, *$ significant at $5 \%$.

\section{Conclusion}

Overall, we found that changing financial reporting regimes for the public sector are costly. Previous research indicates that the costs and benefits of the implementation of accrual accounting and IPSAS are not well understood. This paper provides empirical evidence on the costs of transitioning from the accrual financial reporting framework to the IFRS based reporting framework and subsequently to the IPSAS based reporting framework using the audit cost and effort of auditing as proxies of that cost.

The initial transition from accrual accounting (NZ GAAP) to the IFRS reporting framework for the public sector was particularly costly in NZ, while the transition from the IFRS based framework to the IPSAS based reporting framework was less expensive, although not without additional cost. In addition, it appears from the analyses of the data in this study that auditors had to absorb some of the costs of transition, particularly costs of the transition to IPSAS. Furthermore, the study also found that the costs of auditing across various financial reporting frameworks is also significantly influenced by auditors' specialization, as audit providers that specialize in the public sector tend to be able to provide audit services to the sector at lower costs in contrast to audit providers that are not specialized in the sector. The results of this study have implications for regulators, researchers and accounting standardsetters, as they consider the costs and benefits of changing their financial reporting 
frameworks in the public sector, especially in the countries that are either transitioning in their financial reporting regimes or adopting IPSAS based standards for reporting in their public sectors.

\section{References}

Adhikari, P., \& Mellemvik, F. (2010). The adoption of IPSASs in South Asia: A comparative study of seven countries. In Research in Accounting in Emerging Economies (pp. 169-199). Emerald Group Publishing Limited.

Aggestam-Pontoppidan, C. (2011). Selecting International Standards for Accrual-Based Accounting in the Public Sector: IPSAS or IFRS?. The Journal of Government Financial Management, 60(3), 28.

Ahmed, K., \& Alam, M. (2012). The effect of IFRS adoption on the financial reports of local government entities. Australasian Accounting, Business and Finance Journal, 6(3), 109120.

Ball, I. (2012). New development: transparency in the public sector. Public Money \& Management, 32(1), 35-40.

Benito B, Brusca I. and Montesinos V. (2007). The harmonization of government financial information systems: The role of the IPSASs. International Review of Administrative Sciences, 73(2), 293-317.

Botica Redmayne, N. and Laswad, F. (2013). An assessment of the impact of IFRS adoption on public sector audit fees and audit effort - some evidence of the transition costs on changes in reporting schemes. Australian Accounting Review, 23(1), 88-99.

Bradbury, M. E., \& Baskerville, R. F. (2008). The 'NZ 'in 'NZ IFRS': Public benefit entity amendments. Australian Accounting Review, 18(3), 185-190.

Bradbury, M., \& van Zijl, T. (2007). International financial reporting standards and New Zealand: loss of sector neutrality. Research in Accounting Regulation, 19, 35-51.

Brady, K. (2007). Do NZ IFRS meet the public sector's needs?, Chartered Accountants Journal, 86(10), 19-20.

Brusca, I. and Condor, V. (2002). Towards the harmonization of local accounting systems in the international context. Financial Accountability \& Management, 18(2), 129-162. 
Brusca, I. and Martínez, J. C. (2016). Adopting International Public Sector Accounting Standards: A challenge for modernizing and harmonizing public sector accounting. International Review of Administrative Sciences, 82(4), 724-744.

Brusca, I., Montesinos, V., \& Chow, D. S. (2013). Legitimating international public sector accounting standards (IPSAS): the case of Spain. Public Money \& Management, 33(6), 437444.

Carlin, T. M. (2005). Debating the impact of accrual accounting and reporting in the public sector. Financial Accountability \& Management, 21(3), 309-336.

Carvalho, J., Jorge, S. and Fernandes, M. (2007). Conformity and diversity of accounting and financial reporting practices in Portuguese local government. Canadian Journal of Administrative Sciences, 24(1): 2-14.

Christiaens, J., Reyniers, B. and Rolle, C. (2010). Impact of IPSAS on reforming governmental financial information systems: A comparative study. International Review of Administrative Sciences, 76(3): 537-554.

Christiaens, J., Vanhee, C., Manes-Rossi, F., Aversano, N. and van Cauwenverge, P. (2015). The effect of IPSAS on reforming governmental financial reporting: An international comparison. International Review of Administrative Sciences, 81(1): 158-177.

Ellwood, S. (2003). Bridging the GAAP across the UK public sector. Accounting and Business Research, 33(2), 105-121.

Ellwood, S., \& Newberry, S. (2007). Public sector accrual accounting: institutionalising neoliberal principles?. Accounting, Auditing \& Accountability Journal, 20(4), 549-573.

EY (2016). Changing tack - A new financial reporting framework for public benefit entities. January 2016. https://www.ey.com/Publication/vwLUAssets/EY-changingtrack/\$FILE/EY-changing-track.pdf

External Reporting Board (XRB) (2012). Proposals for the New Zealand Accounting Standards Framework - March 2012. https://www.xrb.govt.NZ/reportingrequirements/accounting-standards-framework/

Government Accounting Standards Board (GASB) (2006). 'Why Governmental Accounting and Financial Reporting is - and Should be - Different', white paper, Norwalk, CT. Available at http://www.gasb.org/white_paper_full.pdf

Grossi, G. and Soverchia, M. (2011). European adoption of IPSAS to reform financial reporting. Abacus, 47(4), 525-552. 
Grossi, G. and Steccolini, I. (2015). Pursuing private or public accountability in the public sector? Applying IPSASs to define the reporting entity in municipal consolidation. International Journal of Public Administration, 38(4), 325-334.

Guthrie, J. (1998). Application of accrual accounting in the Australian public sector Rhetoric or reality. Financial Accountability \& Management, 14(1), 1-19.

Hepworth, N. (2003). Preconditions for successful implementation of accrual accounting in central government. Public Money \& Management, 23(1), 37-44.

Hodges, R. and Mellett, H. (2003). Reporting public sector financial results. Public Management Review, 5(1), 99-113.

Hyndman, N. and Connolly, C. (2005). The impact of introducing resource accounting in Northern Ireland, ACCA, London.

Lande, E. and Rocher, S. (2011). Prerequisites for applying accrual accounting in the public sector. Public Money \& Management, 31(3), 219-222.

Lapsley, I., Mussari, R. and Paulsson, G. (2009). On the adoption of accrual accounting in the public sector: a self-evident and problematic reform. European Accounting Review, 18(4), 719-723.

Laswad, F. and Redmayne, N. B. (2015). IPSAS or IFRS as the framework for public sector financial reporting? New Zealand preparers' perspectives. Australian Accounting Review, 25(2), 175-184.

Mayhew, B. W. and Wilkins, M. S. (2003). Audit firm industry specialization as a differentiation strategy: Evidence from fees charged to firms going public. Auditing: A Journal of Practice \& Theory, 22(2), 33-52.

National Audit Office (NAO) (2002). Helping the Nation Spend Wisely - Annual Report 2002, London, NAO.

Newberry, S. (2002). Intended or unintended consequences? Resource erosion in New Zealand's government departments. Financial Accountability \& Management, 18(4), 309330 .

Newberry, S. and Pallot, J. (2005). A wolf in sheep's clothing? Wider consequences of the financial management system of the New Zealand central government. Financial Accountability \& Management, 21(3), 263-277. 
Newberry, S. and Pallot, J. (2006). New Zealand's financial management system: Implications for democracy. Public Money and Management, 26(4), 221-227.

OECD (2002). Accrual Accounting and Budgeting - Key Issues and Recent Developments, OECD, Paris.

Owhoso, V. E., Messier, Jr, W. F., and Lynch, Jr, J. G. (2002). Error detection by industry Specialized teams during sequential audit review. Journal of Accounting Research, 40(3), 883-900.

Oulasvirta, L. (2014). The reluctance of a developed country to choose International Public Sector Accounting Standards of the IFAC. A critical case study. Critical Perspectives on Accounting, 25(3), 272-285.

Pallot, J. (1991). 'Accounting, Auditing and Accountability', in Boston, J., Martin, J., Pallot, J. and Walsh, P. (Eds.), Reshaping the State: New Zealand's Bureaucratic Revolution, Oxford University Press, Auckland, pp. 198-232.

Pallot, J. (1992). Elements of a theoretical framework for public sector accounting. Accounting, Auditing \& Accountability Journal, 5(1).

Pallot, J. (1998). 'The New Zealand Revolution', in Olson, O., Guthrie, J. and Humphrey, C. (eds), Global Warning! Debating International Developments in New Public Financial Management, Capellen Akademisk Forlag As, Oslo, pp. 156-84.

Pilcher, R. and Dean, G. (2009a). Implementing IFRS in local government: Value adding or additional pain? Qualitative Research in Accounting \& Management, 6(3), 180-196.

Pilcher, R. and Dean, G. (2009b). Consequences and costs of financial reporting compliance for local government. European Accounting Review, 18(4), 725-744.

PwC (2016). In Brief - Are you ready for the transition to PBE Standards?, Issue No. 1. Available at https://www.pwc.co.NZ/pdfs/pbe-in-brief-february-2016-not-for-profitstransitioning-to-pbe-standards.pdf

Robb, A. and Newberry, S. (2007). Globalization: governmental accounting and international financial reporting standards. Socio-Economic Review, 5(4), 725-754.

Roje, G., Vasicek, D. and Vasicek. V (2010). Accounting regulation and IPSAS implementation: Efforts of transition countries toward IPSAS compliance. Journal of Modern Accounting and Auditing, 6(12), 1-16. 
Rossi, F. M., Cohen, S., Caperchione, E. and Brusca, I. (2016). Harmonizing public sector accounting in Europe: Thinking out of the box. Public Money \& Management, 36(3), 189196.

Stevenson, K. M. (2010). Commentary: IFRS and the domestic standard-setter - Is the mourning period over? Australian Accounting Review, 20(3), 308-312.

Solomon, I., Shields, M. D. and Whittington, O. R. (1999). What do industry-specialist auditors know? Journal of accounting research, 37(1), 191-208.

Trewavas, K., Botica Redmayne, N. and Laswad, F. (2012). The impact of IFRS adoption on public sector financial statements. Australian Accounting Review, 22(1), 86-102.

Wynne, A. (2007). Is the move to accrual based accounting a real priority for public sector accounting? Public Fund Digest, 6(1), 25-39.

Wynne, A. (2008). Accrual accounting for the public sector - A fad that has had its day. International Journal on Governmental Financial Management, 8(2), 117-132. 
Evidence on the costs of changes in financial reporting frameworks in the public sector

Redmayne, NB

2021-07-04

22/04/2023 - Downloaded from MASSEY RESEARCH ONLINE 